\title{
Reality and Finnish TV Criticism
}

\author{
IIRIS RUOHO
}

This article examines realism conceptions in Finnish TV criticism. The analysis concentrates on journalistic evaluations of long and middle-length serial dramas in TV2 (YLE) between 1961-1996. The intention is to analyze in detail in what ways journalistic television criticism has seen as important or less important the fact that series in one way or another participate in reality. The article starts with conceptualization of 'realisms' and continues by considering the substance of journalistic television critique, and its special characteristics.

Following conceptualization, the article gives an empirical overview of the data, which consist of 411 critiques of different kinds. The qualitative analysis concentrates on reviews and critiques written about the following family series: Pääluottamusmies (1970), Rintamäkeläiset (1972), Oi kallis kaupunki (1975), Tankki täyteen (1978), and Kohtaamiset ja erot (1994). These five series are chosen because of their comparability and distinctiveness as regards the selectivity of social realism as convention and the 'utility drama' as discourse.

As the study shows, the majority of the critiques establish some sort of a relationship between the dramas and 'reality' as well as the critics' assumed connection to reality. On the general level of the analysis, these relationships and connections can be examined from three points of view, following Stuart Hall's analogy on language (Hall 1997, 2425): reflective, intentional and constructionist. With the first view, critics evaluate whether or not existing reality is reflected in the TV series. According to the second view, the author, for example the writer or director, is considered to have her or his own unique way of seeing and talking about re-

Department of Journalism and Mass Communication, University of Tampere, FIN-33014 Tampere, tiiiru@uta.fi ality that can also be recognized by critics. In third case, criticism fairly openly builds its own reality, seemingly independently from the 'reality' portrayed in television drama.

\section{Conceptualizing Realism}

'Realism' has had many different interpretations in Finnish television culture. What the interpretations have in common is a conception of reality, which the series should readily mirror or bring to the viewer according to journalistic reviews. The requirement of realism for the serials is that they should be close to our everyday thinking and help in our attempt to 'accept things as they are'.

In academic use, 'realism' has referred to the historical $19^{\text {th }}$ century bourgeois ideologicalesthetical movement, and to 'realism' as the ideology of text (compare O’Donnell 2000, 215-216). Because the perpetual confusion between different concepts makes 'realism' hard to define, one alternative to the conceptual confusion is to make a division between the academic term 'realism' and the everyday term 'realistic' (Williams 1976, 215; 1989, 226). Realism, as a method, makes it possible to combine different world-views, different ways of treating characters, and different narrative attitudes, places and actions (Williams 1977, 173179).

Realism is a flexible convention whether it is regarded as a textual property of a television series or as a political effect of 'the text'. However, the conventions that describe 'reality' - to which the majority of Finnish television drama belongs - disguise their own construction. In other words, in its attempt to describe things 'as they are' or 'how they should be', the convention of realism simultaneously constructs itself either as the presence of 'truth' or as its adequate reflection in the television series. 
According to ideology critique, 'realism' is not the presence of some genuine and unadulterated 'reality' (or, in its extreme, naturalism), or something that can be outlined with the eyes and ears, either in fact or in fiction. Views on the realism of television are also ideological. The data collected from the newspaper archive of the Finnish Broadcasting Company shows that television critics published in newspapers do not normally question their own ideas of what they consider as a realistic or an unrealistic feature in fiction.

As mentioned, these hegemonic views, which are critical of realism, are joined by a third, rather rare view in journalistic reviews of television shows, that which takes into account the social and productive aspect of language, and thinks of 'realism' as the product of text. This view warns us not to confuse true reality with the material world, where we act with those symbolic practices and processes whereby representations and meanings derived from 'reality' operate.

\section{Criticism in Newspapers}

Newspaper critics have mainly had a social approach, concentrating on the content of a series. They have considered the reflection of reality in a series, but surprisingly often, this has been done in relationship to the series authors' unique relationship with reality. The 'realism' that has been expected from the series has, however, been essentially something other than the empirical, emotional, ethical, pedagogical or historical realism that the critic has recognized. It has been, and still is possible, to combine the demand for reality with the demand for social priming. In other words, the critic expects the events in the series to be worked over in such a way as to make them become significant to the audience, and even finally become objects for action. This view indirectly contains the idea that a realistic or unrealistic television series in the end materializes as social action or non-action.

The 'macro institutions' of television criticism can be divided, according to the model presented by David Bordwell, into journalistic and essayistic writing and academic scholarship (1989, 19-20). Certain media and ways of expression correspond to these institutions, such as newspapers, and professional, academic and club journals. I add administrative and professional institutions to the list. For example, The Finnish Broadcasting Company has its own publication series, which from time to time publishes material that can be regarded as program critique. In addition, their internal magazine Mediavirtuoosi ${ }^{1}$ published annual reviews of programs, and the making of programs. These particular reviews were written by television professionals and researchers.

Apart from the publication medium, formal and informal institutions, critic organizations, colleagues, schools of thought and different types of social networks also influence the way in which television reviews are presented. These all shape the critic's routines and practices. The previewing of programs makes it possible to influence the critic's opinion, which brings the job closer to that of the film critic who writes for newspapers. Previewing gives the critic at least a theoretical chance to influence what viewers choose to watch on television. At the same time it is possible that the collegial banter in previewed shows may have its own influence on how individual critics form their opinions.

It is worth bearing in mind that neither journalism in general nor journalistic television critique has any sort of universal character. Journalism has a social and historical nature, and, for example, the concept of critique in reviewing art and literature is a product of modern times. As Ari Kivimäki says in his study on movie journalism, there has been strangely little research on the relationship between critique and journalism, although a significant part of (movie) critique has always been placed in the mass media (Kivimäki 1998, 26). What still remains to be considered is the connection between critique and journalism and the modern articulations of enlightenment, progress and democracy, with social control, passivating citizens and the production of consumerism as the connection's possible downsides (compare Hartley 1996, 31-56).

The traditional place for journalistic television reviews is in newspaper TV and radio pages. Professionals who specialize in this genre and write under their own bylines mainly write TV reviews. However, in the data there are some reviewers who use a pseudonym. According to the characteristics of journalism, the reviews consist of reporting and commentary, and they fairly seldom make use of the viewpoints of academic criticism. Sometimes television program reviews are given space in other sections of the newspaper than in the TV and radio pages. Long reports and editorials on individual programs are, nevertheless, rare and mostly connected with some general debate concerning, for example, the production of a television series and manuscript writing or thematic issues, such as violence on television. 
The above 'macro institutions' of television criticism can be compared with Pierre Bourdieu's familiar ideas about 'fields'. Journalistic television criticism is perhaps not as canonized as film criticism. There is, however, an ongoing symbolic battle over, for example, the aesthetic criteria for distinguishing between serious and entertaining television production. Nevertheless the critic may find herself more closely tied to the prospective audience of the newspaper rather than to any particular aesthetic field. Every kind of battle, debate and articulation requires specific cultural capital. In the data I have examined, a clear distinction is also formed between individual critics.

The classification Merja Hurri has made of cultural journalism works well in describing the television reviews examined here as articulations which each work most strongly in their given cultural fields. As Hurri remarks, the critic may be connected with the field of art (aesthetic professional critique), the field of journalism (journalistic or ideologically committed critique), or the audience (popularizing critique). These connections have their pros and cons. If the person who writes the critique is, herself, an artist and committed to this reference group, independent professional cri- tique may, at worst, be awkward and difficult. A corresponding difficulty arises if the critic is very committed to the ideological stance of her newspaper. A critic with strong ties to her audience is seldom found in art criticism; instead she is often found in the TV pages of newspapers. A television critic committed to her audience writes in an intelligible way and popularizes the critique according to the presupposed norms of the audience. (Compare Hurri 1994, 7-8.)

\section{From Combined Reviews to Puffs}

The data presented in the table below cover the time period from 1963 to 1996 and the serials I have chosen mainly represent the family drama genre. ${ }^{2}$ I have classified the reviews into eight categories depending on how they treat the series and serials under investigation. The largest group, 128, is the group of combined reviews, where more than one television program is written about. In the combined review the series or serial is one program among a number of others. The next largest group is the group of puffs that concentrate on the series and serials, a total of 122 . They portray and advertise the dramas by making use, among other things,

Table 1. The Serials under Investigation and the Television Critique Written about Them

\begin{tabular}{|c|c|c|c|c|c|c|c|c|c|}
\hline Series/serials & $\mathrm{N}$ & 1 & 2 & 3 & 4 & 5 & 6 & 7 & 8 \\
\hline Heikki ja Kaija (1961) & 55 & 33 & 4 & 3 & 6 & & 4 & & 5 \\
\hline Kiurunkulma (1966) & 30 & 19 & & 5 & 2 & & 2 & & 2 \\
\hline Pääluottamusmies (1970) & 22 & 9 & & 10 & 1 & & 2 & & \\
\hline Rintamäkeläiset (1972) & 35 & 21 & 3 & 7 & 3 & & 1 & & \\
\hline Oi kallis kaupunki (1975) & 24 & 14 & & 8 & 2 & & & & \\
\hline Tankki täyteen (1978) & 24 & 5 & 6 & & 5 & 7 & 1 & & \\
\hline Reinikainen (1982) & 38 & 10 & 13 & 7 & 2 & 4 & 2 & & \\
\hline Mummo (1987) & 22 & 3 & 11 & 4 & & 3 & & & 1 \\
\hline Rivitaloelämää (1989) & 7 & & 5 & & & 1 & & 1 & \\
\hline Huomenna on paremmin (1993) & 6 & & 6 & & & & & & \\
\hline Hyvien ihmisten kylä (1993) & 12 & & 8 & 1 & 1 & 1 & 1 & & \\
\hline Kohtaamiset ja erot (1994) & 16 & & 10 & 2 & 3 & & 1 & & \\
\hline Onnea vai menestystä? (1995) & 12 & 2 & 7 & 2 & & & 1 & & \\
\hline Lähempänä taivasta (1996) & 15 & 1 & 8 & 1 & 3 & 1 & 1 & & \\
\hline Kyllä isä osaa (1994) & 18 & 1 & 13 & 1 & 1 & 1 & 1 & & \\
\hline Elämän suola (1996) & 18 & 2 & 10 & 2 & 2 & 2 & & & \\
\hline Metsolat (1993) & 57 & 8 & 18 & 6 & 6 & 12 & 1 & 2 & 4 \\
\hline Total & 411 & 128 & 122 & 59 & 37 & 32 & 18 & 3 & 12 \\
\hline
\end{tabular}

An explanation of the table follows: $\mathrm{N}=$ the number of reviews (stories) per serial, 1 . Combined review, part of which is a review on the program, 2. Concentrated puff review, 3. Concentrated review, 4. Referring combined review, 5. Referring puff in connection with another individual program, 6. Referring review in connection with another individual program, 7. Other referring review, 8. Other concentrated review. 
of the channel's own press material. There are 59 concentrated reviews, which only write about the drama in question.

Combined reviews, which only refer to the series or serials, are in total 37 . Reference is made in them to the drama under investigation, although the review itself is compiled of reviews of programs other than the dramas themselves. Referring puff (32) differs from the previously mentioned category in that it concentrates on giving free media advertising to some other program than the one it also refers to. There were 18 reviews in the data that concentrated on one other program but referred in one way or another to the researched series and serials. Other reviews, which do not fit into the above categories and which either refer to or concentrate on a program, total 14 . The real subject of these reviews is normally something other than programs themselves such as, for example, program policy. ${ }^{3}$

In the preliminary reading of the newspaper reviews, I have made the following categories concerning the relationship of the reviews with reality: empirical, emotional, psychological, didactical, thought provoking, correcting, generic, ethical, redemptive, mythical and historical. The most common one is the empirical relationship, which refers to the concrete reality depicted in the series and its verisimilitude, genuineness or credibility of events (see Ang 1985, 36-37). Emotional reality is sought in the treatment of emotions and believability of characters. Didactical, thought provoking and corrective relationships (see Deming 1988,154) are connected with the wish to say something or influence the audience's consciousness or actions with certain desired portrayals. Ethical realism is close to redemptive realism (compare 'redemptive reading' Brunsdon 1989, 121). With either moral, or, for example, gender political grounds, both expect a certain treatment of things or emotions. With mythological realism, I refer to the depiction of Finnish mythology, although the serial may have fantasy as its genre. Historical realism refers to both the expected or politically correct depiction of historical events.

This chapter deals with most of the above-mentioned expectations of reality as they have been used in connection with the series and serials in the newspaper reviews. As will be shown later, a number of different expectations of reality can be connected with the same drama.

Rintamäkeläiset, which is also one of the objects of my qualitative analysis, took place in a remote village in the countryside, and was broadcast at intervals from 1972-1978, in 30 episodes. The 12-episode Tankki täyteen $(1978,1980)$, which was produced by the Entertainment Department, told the story of gas station owner Sulo Vilen and his numerous cut-price business ideas which all came to nothing. The most recent of the programs examined, the 21-episode Kohtaamiset ja erot took place in the imaginary Kärttämä village, to which a woman named Inkeri comes from across the eastern border with Russia to Finland. Less known to today's audiences are probably the 25-episode drama production Kiurunkulma (1966-1969), the 8-episode Pääluottamusmies (1970-1971), and the 9episode Oi kallis kaupunki (1975).

Kiurunkulma is a story built around a health clinic and tells about life in a remote village, and especially about different religious prejudices, social problems and their solutions. The expression of the serial is sometimes semi-documentary, with problems depicted straight from 'reality'. The episode-like Pääluottamusmies takes place in and around a big industrial plant in a medium-sized city where the main character and other family members try to solve seemingly irreconcilable conflicts between workers and employers. The series attempted to achieve strong authenticity in its portrayal. Oi kallis kaupunki, which had a continuous story line and was mostly, therefore, labeled a soap opera, was also situated in a medium-sized city, but took as its subject matter municipal politics and the idealism of a young fledgling politician. The story concentrates on a wealthy shop-owner family whose mother, as the narrator, is confined to a wheelchair and is ruthlessly writing a book about the things she sees and hears. As with Pääluottamusmies, this filmed television series focused on class relationships, which were common in the 1970s.

Inclusion or exclusion from convention is a discursive, selective process, an example being tradition (see the selectivity of tradition Williams 1977,115). The criterion of convention cannot, thus, be completely reduced to the characteristics of any individual series and serial. For example, series that deal with working life or social problems in general, such as Kiurunkulma and Pääluottamusmies, do not fulfill the criterion of family drama, but have a flexi-narrative form (see Nelson 1997, 30-49). The families of the main characters have, however, a central role in these series, or things are looked at from time to time from the point of view of the families in trouble, especially when solutions are sought. The general social problems depicted in the series in the 1960s and 1970s can be regarded as addressing 'family interest' at 
that time as the programs dealt with common social and health problems. I will now take a closer look at how difficult it has been for television critics to define the serial convention and its characteristics. This is especially the case from the point of view of realism.

\section{Utility Drama}

Heikki ja Kaija is written about in the data as an everyday drama by which is meant, quite simply, a realistic depiction of everyday life. When they write about Kiurunkulma, critics also use the concept of utility drama. It is impossible to say where this concept first entered the vocabulary of television critics. I first encountered it when I was interviewing people who were involved in the production of drama series and serials. It may be possible that the concept originates in television productions from where it has been picked up by critics. The concept resembles the derogatory label kitchensink, which has been used not only in connection with bleak everyday realism but also in describing the haphazard way of making a film. Utility drama has contradictory contents: it is connected with both positively experienced empirical topicality and didactics and with negatively experienced entertainment and an overtly contemporaneous feeling.

A television critic writes in 1968: "'Kiurunkulma' is an educational series, a utility drama, as the term now goes, a topical portrayal of everyday things" (Iisalmen Sanomat 9.7.1968). Another critic continues: "So far the events have taken place in the safe and sterile environment of the health clinic where two fragile nurses, under the guidance of a stern cleaning lady, give out advice against tapeworm and for birth control. The staff of the clinic are the necessary "good" which is connected with educational TV series (Savon Sanomat 23.9.1968)". A few years later when writing about Rintamäkeläiset, Tapani Uusiniitty, who has also written film reviews, remarks that

The Tampere known from Heikki ja Kaija has been changed to the countryside in the borderlands between Häme and Satakunta, where a small farmer and his family, live in the new series on TV 2 by Reino Lahtinen. Finnish country reality $[\ldots]$ has been used as the backdrop for the events and situations, but at least in the first episodes, the factual elements have been blotted out in favor of entertaining and contrived personal relationships, and problem settings familiar from utility drama. (Aamulehti 5.10. 1972.)

Uusiniitty adds to his views later:

[...] Rintamäkeläiset was even at the beginning of its rerun a commercial mixture of everyday life, and a folk piece. The subject matter is taken from country reality, but it is interpreted in a formal and stereotyped way. The people are caricatures, their speech slow, and the situations artificial. When problems are presented, statements and self-evident things suffice. There is not even an attempt to find other than facile solutions. (Ilkka, Lalli and Karjalan maa 27.10. 1974.)

On the one hand, the slow treatment of things that seemed very ordinary irritated especially the contemporary critic who was used to film aesthetics, but on the other, the entertaining aspects were not completely condemned. Uusiniitty, who was famous for his critical writings, was thus able to write: "Rintamäkeläiset belongs to those play-like television programs, which in the late hours of Tuesday nights compete for spectators. A fast-made entertainment program loaded with trivia, it is cheap theater but still belongs to the vanguard of domestic productions." (Aamulehti 1.12.1972) That the views seem conflicting in the first decades of television history stems from the difficulties there were in the aesthetic definitions of what constituted fictional television series.

Utility drama in the critique also refers to some sort of aesthetic disposability. 'Utility drama', as their makers' premise, was obviously used at that time to highlight the production of the new form of drama, the television series. The making of television series and serials in Finland was not really 'industrial' production, but on the other hand it did not have the label of creativity that is connected with individual artistic production either. Pertti Nättilä (1996), a director I have interviewed, said that series were regarded as disposable items at the time. It was not thought that the series would have much utility value later. The makers of the series thought that the serials were "products of their times", and that they were not really regarded as belonging to the category of Television Theater or drama (Rönty 2000, 13).

As a definition, utility drama strongly implicates the fact of being time-bound, which is related to the view of television as the portrayer of the present, as a 'window to reality', which works 'here and now'. In this case the wish for empirical 
realism in the drama is strong. Being time-bound also implicates the speed of production and the fact of tackling topical questions, which was typical of the time and perhaps partly inherited from the live broadcasts at the beginning. A television series was not so much thought of as drama but as a program amongst others. A fictional series could also be given clearly journalistic tasks. According to Eero Silvasti (1996), one of the ideas of the 1960s and the early 1970s was the report play, a depiction of the present. They were quickly made outside studios and they had a journalistic starting point. Palveleva puhelin (Hotline) (1970-1971) was one of this kind of series. It was written as eight minidramas based on the stories and the problems filtered through the national church hotline.

\section{Social Realism}

The concept of utility drama occurs only in connection with the above-mentioned series from the 1960s and early 1970s in the newspaper data I have examined. Yet, for example, the director-writer, Jussi Niilekselä (1996), still uses it when he speaks about the serial dramas of the 1990s. But in these cases, the author is emphasizing the nature of the series and serials as less artful products rather than highlighting their disposability or their commitment to the present. Apart from the negative interpretations of utility drama, the contemporary critics also speak about the above-mentioned programs as "humane, everyday dramas". Such interpretations bring the utility play closer to the convention of social realism.

This convention was introduced in academic television critique by Marion Jordan in her reviews of the British soap opera Coronation Street (19601990). To sum up her definition of the convention: social realism depicts human life in a way in which the personal relationships of the central characters form the center of events. Although the events mainly consist of social problems familiar to the working class or to groups close to it, they are, according to the conditions of the convention, always experienced individually and the characters themselves solve them. Despite class ties, 'ordinariness' is emphasized in the convention of social realism, be it in connection to the portrayal of homes and families, or with friends. The serials take place in urban environments and provinces and their sets are generic, recognizable places - such as the pub, the street, the factory, the home, or especially, the kitchen. The time perspective is the present and the events are filmed so authentically that the audi- ences end up feeling that they have spent their time at the expense of the filmed characters. (Jordan 1981, 28.)

Rintamäkeläiset was in a class of its own in the history of Finnish social realism. Because of the strong characterization of its central roles, it differed from Heikki ja Kaija, which was produced by the same team. It also lacked the educational and partly improvised tone of its predecessor. More was also invested in making the characters believable. The series started in 1972, and was shown a few episodes at a time; it continued for seven years and recounted the life of a small farmer in an unassuming way without taking sides. However, the central characters represented different political party stances in which the unwavering Rural Party views of the farm owner provided an on-going tension. The neighbors were social democrats, communists and conservatives. Municipal politics were still dealt with as a minor sub-plot, among the other preoccupations of the small farmer.

In critiques there are quite a number of remarks about the aesthetics of this serial drama as compared to earlier series. The strong characterizations especially irritate the critics; in their minds the people are not completely believable psychologically. Accurate details, such as the bleak country life, are also buried beneath the representation, as the following excerpts from Tapani Uusiniitty and Jukka Kajava show:
The fall season also brought to viewers the new serial play by Reino Lahtinen Rintamäkeläiset, which depicts the life of a Finnish farming family. However, Rintamäkeläiset has, in its early episodes, contained so much ordinary si- tuation comedy and biased superficial humor that the accurate depiction of grim country life has been buried underneath. (Aamulehti 29.12.1972.)

The show is like a confused combination of four types of play performances. There is the folk performer, Veijo Pasanen's farm owner, the gossiping comedy hag, Ella Roine, and curiously enough, characters who seem genuine, such as Sirkka Lehto's wife and Matias Ikävalko's, Aarne. The sum of all this confusion is that we get TV drama that is intellectually muddling and tastes like theater, where some are disciplined, and some hop over where the fence is the lowest. (Helsingin Sanomat 30.1.1973.)

However, all critics do not agree. Aimo Siltari is in favor of the characters, which he sees as informative, not as realistic: 
The people talk with a Tampere accent, and of the two small farmers, one is a social democrat and another votes for Vennamo. The characters are unadorned, but real. Veijo Pasanen's Vennamo-voting type can also be regarded as informative; somehow generalizations are made and these do not have to be based on anything or be universally applicable. But it works well. The social democrat is made into a sympathetic mediator, the Vennamo-voting guy is, by his mental make-up, a gloomy and cranky man, the family tyrant, oppressor of women. (Savon Sanomat 6.10.1974.)

What is interesting in this review is the mutual exclusion of realism and informativity; neutrality (the 1960s), impartiality (1970s) and offering viewers fact-based material were the cornerstones of the informative program policy. Apparently simplification and characterization were used to achieve what Siltari thought of as the feeling of authenticity, and the adequate degree of generalization, which did not necessarily achieve the universal applicability required by realism. Raija Laroma (presently Oranen), for her part, regarded the strength of the series to lie in its depiction of a way of life, this being accomplished by the use of little details, small everyday things and individual characteristics. All these are features associated with social realism. However, she too warns of excessive adherence to details at the expense of general characteristics. (Hämeen Yhteistyö 7.10.1972)

\section{Journalistic Drama}

Utility drama gets an interesting articulation when it is combined with a positive didactic aspect, which seems to be something that is expected of serial drama makers. Of Kiurunkulma the reviewers notice how different kinds of problems are boldly brought out, and how advice is given - not necessarily how reality as such is depicted. What was common to all TV 2 black-and-white series in the 1960s was the meticulous background work and documentary expression that was made possible by the ample use of outside broadcasting technology ${ }^{4}$ originally intended for current affairs production. It was programmatic that in the production of the serial drama the makers went outside the studios and used real people, both in acting as themselves and as experts in the background. Writer Liisa Vuoristo and director Eila Arjoma used the views of contemporaries and different experts in the construction of the serial world. Their insights were then worked over and became parts of the fiction. They used this method still when they were making the drama Mustat ja punaiset vuodet (1973).

The pseudonym, Tee Ärrä, wrote that Kiurunkulma represents up-to-date, sharp social criticism. The episode "Horse-trading" depicted orthodox Laestadian belief, which forbade abortion for a mother of twelve children. The pseudonym comments:

We have to get even the stupidest to wake up from their state of indifference, which is so typical of our forest nation. We do not much care to bother our heads, not to mention our hearts, with other people's difficulties. And it is even harder to quit complaining and start real and effective action. When one thinks about those many acutely interesting subjects that the alert and aware writer could find in the history of our nation, one has to marvel at the banal serial drama that is continuously being shown. (Päivän Sanomat 4.9.1967.)

But on the other hand: "If utility drama means that the lesson has to be given more clearly than just pointing your finger, then Kiurunkulma is such at its purest; its lesson comes like a fist in the face..." (Iisalmen Sanomat 9.7.1968). Or like the pseudonym, Puntari, says:
Kiurunkulma, as opposed to Peyton Place, has been a completely domestic and relatively little romantic serial drama, which is probably made in the spirit of enlightenment rather than in the spirit of entertainment. Monday's episode ("Fined", IR) with its native Maigret variations was an education in the style of beautiful and idealistic books for young people. Kiurunkulma has had some very good episodes, and more than Peyton Place, it should counter-balance Tammelat: teachings in the style of juvenile literature and offering wholesome role models to an already guilt-ridden nation should be limited to only one domestic serial drama. (Vaasa 7.5.1968.)

The style of Kiurunkulma is close to neorealism (compare Steinbock 1985, 92), which brings up current problems and avoids excessive optimism. Neorealism is typical especially of some Finnish films made in the early 1970s. In the core of neorealism there are social problems, which are often filmed in authentic locations with the use of amateur actors. Markku Rönty finds elements of this style also in Rintamäkeläiset which, according to him, and unlike Heikki ja Kaija, deals with Finnish 
society with the eyes of the underdog. This interpretation is exaggerated, however, because 'the realism' of Rintamäkeläiset lies in the tradition of boulevard comedy. Although information, for example on the benefits of the welfare state, has been important in other Finnish serial dramas, they are, above all, representatives of social drama.

Instead, the way things are treated in Kiurunkulma resembles that of journalism, and of all the series dealt with in this work, it seems the best representative of time-bound 'utility drama'. With its affirmation of new things and attitudes, Kiurunkulma is totally different from the other series discussed here. In its time, it fulfilled the aim given to program production at the Finnish Broadcasting Company, to offer a worldview that was based on "true information and facts". The guidelines presupposed that the Finnish Broadcasting Company has "the right to resist social problems by the means of commentaries, discussions and talks without taking into account commercial, political party affiliations and other less relevant ends" (Guidelines of program production 1.11.1967, 1 §; Zilliacus and Storbom 1968).

The series received praise from the then inspectors of the channel ${ }^{5}$ who in their report, The Worlds of Serial Drama (Harms, Rand \& Savolainen 1970, $155)$ noted that as the only series dealing with 'contemporary circumstance' it has chosen its own path. According to the report, the series takes its material from the reality of Finnish society, the life of the residents being set in the larger social framework. It also attempts to show where problems could be solved at the level of the society. Journalistic reviews also commented on the program policy, as evidenced in the following examples. The examples also show that the channel's programs had begun to be shown on the so-called national network. It was a time when TV 2's coverage area was geographically limited and the channel had to fight for its position as the so-called transmission channel:

As a counter-balance to the mainly city-oriented imported programs and the domestic Tammelat, Tarinatalo and Heikki-Kaija its makers have gone into the problems of remote areas, often gone into and drawn the audience's attention, sometimes dramatically, sometimes documentarily, to problems that need to be solved (Suomenmaa 29.10.1968.)

Bringing TV 2 into the national network is the most informed of the recent program policy decisions, as long as TV 2 is able to produce serial entertainment, or should one say series contemplation, in the league of Kiurunkulma. (...) Once again one has to wonder about that symptomatic congestion that governs our TV thinking. A censorship mood is brought out when it comes to progressive and forward looking programs, but nobody demands that, for example, Tammelat should quit if this demand should be made again. Now that Kiurunkulma shows what a TV serial can be in its importance. (Savon Sanomat 10.1.1969.)

Enlightenment without political side-taking seems to have earned praise for a series, which was produced and broadcast at the time of the so-called Reporadio. Although some factual programs were aggravating and TV 1 Television Theater tried the patience of decision-makers by going against bourgeois hegemony (Salokangas 1996, 217-245), this was not the case with fictional television series and serials. The critics tried to harness the 22-episode Hilma (1967-1968) as a part of the informative program policy. A television critic writes that the series "could very efficiently be used to illustrate, for example, the problems of pensioners" (Turun Sanomat 2.6.1968).

It is easy to understand how the things presented in Kiurunkulma did not aggravate politicians to the same extent as factual programs and some cabaret-style entertainment programs. The politics represented in the series did not appear so much as party politics or as criticism of parliamentary politics, but as conservative attitudes, which the series really tried to shake. In spite of, or really because of, its congenial reception, Kiurunkulma will remain in Finnish television history as a paradigmatic example of the original way TV 2 theater productions interpreted the informative program policy. Unlike any other series before or after, each episode contained an individual message, which was meant to make the audience think about what they were watching. In the criticism, the realism represented by the series is not exhausted on the social problems that it deals with, but in the attempt to solve those problems.

\section{In the Middle of Politics}

Both Pääluottamusmies and Oi kallis kaupunki clearly took politics as a part of the lives of the people in the series. Pääluottamusmies, which started in 1970, reviewed things from the point of view of the labor union movement. The series, which was set in the Enso Gutzeit paper mill mi- 
lieu, was talked about in the critiques not only as a representative of social realism but also as an informative series. The episodes dealt with the work of the union steward, the internal problems of the labor union, industrial democracy, collective agreements, wage policy and occupational safety. As the TV 2 press release on the replay of the first five episodes shows, the makers of the series meant that "Above all, a better society calls for internally changing and more enlightened people and undoubtedly every union steward - whatever he may be seen as and in whatever position - will become convinced of this in his own position as an elected representative" (TV 2 1971).

The representation of party politics, and especially that of the communists, was regarded as biased and suspect in the critique published in the leftist newspapers (Kansan Uutiset 28.10.1970 and Kansan Tahto 14.8.1971) ${ }^{6}$. According to the reviews, the writer has "placed in his manuscript elements which unequivocally do not lead to the strengthening of the workers' co-operation in the workplaces" (Kansan Uutiset 2.11.1971). At the same time the depiction of the workplace milieu and the topicality of the subjects handled were praised without restraint. Apart from the praise, the series was also criticized for being "too" entertaining. T-B Orsmaa wrote:

It has been exceptional to see in TV, which is colored by bourgeois values, a series in which things in a large industrial plant are seen from the point of view of workers. The problems the union steward faces have been convincingly truth-like. All this has clearly been a plus. Apparently the makers of Pääluottamusmies have wanted to find an entertaining "package", and, therefore, there are irrelevant sub-plots tied up in the story. Such was the love story between the owner's son and the daughter of the communist worker, which in the last episode was solved forever after in a happy marriage. The ending was a clumsy compromise between two opposing social classes. In spite of these subplots Pääluottamusmies has been an important step on the road to informative and interesting serial drama. (Savon Sanomat 30.7.1971.)

In the TV critiques the makers are praised, both the journalist from Kotka, Jorma Savikko, and his familiarity with the world the series depicts and the director Rauni Mollberg and his "profound setting for the subject, capable handling of the milieu and expert treatment of the actors and especially, the amateurs" (Turun Sanomat 26.10.1970). According to Jorma Savikko himself (1996), in the background work for some of the episodes, he really interviewed people whose lives and environment the series depicted. This was made easier by the routine adopted in a journalist's work, and also in local knowledge of the labor union. In some of the critiques there are references to Savikko's and Mollberg's earlier, successful co-operation in the filming of Toivo Pekkanen's novels. Ahti Sala describes the authenticity of the milieu and the topicality of the subject matter in Pääluottamusmies in the following way:

It opens the gates for the viewer to a less pleasant
environment: a noisy world paced by extremely
fast work. In this anthill, the union steward is
the key person, the representative of the work-
ers, through whom words are exchanged and
negotiations made with the employer. The play
is set in an important time period, right now is
the time for collective bargaining. Now reso-
lutions are made of things, which are of vital
importance to the workers. Now in all produc-
tion plants and factories union stewards and
workers face important problems. (Hämeen
Yhteistyö 27.10.1970.)

In the journalistic writings of Pääluottamusmies, the main importance is given to the views on the authenticity of the series. The things dealt with in the series are hardly criticized, although the way they are treated may give cause for differing views. According to the critique, this is where realism in the series can be found: in the depiction of actual milieu and of real things, in showing things 'as they are'.

New broadcasting guidelines came into force in the same year as Rintamäkeläiset started, in 1972. One of the central concepts in the broadcasting policy declaration was 'objectivity', which replaced 'impartiality' in the 1967 guidelines. The Finnish Broadcasting Company was supposed to, "in as many-sided a way as possible, bring out in its programs 'different opinions, values, ideologies and other social phenomena' in proportion to how they actually occur". However, objectivity was understood in a wider sense in the guidelines, so that, for example, mere achievement of a balanced political viewpoint was not enough to fulfill the license guidelines. (Finnish Broadcasting Company, Broadcasting Policy Guidelines 1972, 2).

The information warfare, which in the early 1970 s concentrated on broadcasting policy ${ }^{7}$, showed that the struggle for political hegemony had become an increasingly important part of the de- 
bate surrounding the Finnish Broadcasting Company. According to one interpretation, cultural radicalism, which paved the way for the early years and the founding principles of the so called Reporadio, tapered off in the late 1960s as left radicalism, and in television culture the turn of the 1970s meant a turn towards right-wing politics (see Steinbock 1985, 91). However, television criticism written about either Pääluottamusmies or Rintamäkeläiset shows little serious indication of a battle over hegemony. From the point of view of realism, their depiction of politics is, above all, expected to be redemptive; all political movements have their place in society. The changing social situation is gradually starting to be interwoven within the debate on television serials, such as in reviews written on The Oi kallis kaupunki [My Dear City] (1975) show.

\section{A Finnish Peyton Place}

The serial, which openly depicts municipal politics, tells in its nine filmed episodes about the municipal politics of a medium-sized city, commonly viewed as the town of Lahti, about the leaders and their supporters. In a press release available from 1975 , the intention was to make a portrayal of people in the 1970s and of their relationship with those who held power. The press release says that originally the series was meant to have dealt with this issue from the vantage point of a party secretary. However, they gave up on this idea and chose a citizen, and more specifically the inhabitant of a municipality, as the spokesperson of this world. The series is said to be "a TV film that tells the story of a young conservative businessman and pop singer, and his development from a jet setter to an aware citizen of society". (TV 2 1975)

TV criticism pointed out the blurring boundaries of cinematic TV serials and serial drama (Etelä-Saimaa and Kainuun Sanomat 20.2.1975 and Itä-Savo 1.3.1975). Pääluottamusmies already resembled a film more than a TV series if the pictorial aesthetics of Heikki ja Kaija and Rintamäkeläiset were the criteria. In addition, the main character's relationships with women, the internal conflicts of the family, the political horse-trading and the overall speculation in municipal politics gave the new serial with a continual plot its own formal characteristics which are different from the earlier TV 2 serial drama productions.

Oi kallis kaupunki is compared in critique with the television melodrama Peyton Place, bought by MTV. (Liitto 5.4, Helsingin Sanomat 8.5. and 5.6., and Uusi Suomi 7.6.1975). Newspapers said that "unfortunately life is quite a Peyton Place around the world: climbing towards the top with a glint of money in its eye and the song of the cash register in its ear" Turun Päivälehti 14.6.1975. This sentence illustrates well the 'reality talk' characteristic of television critics to which I will return later.

What is remarkable in the critiques of the serial are the remarks related to the continuous plotting and huge cast, which take attention away from the discussion of how realistic the serial is. On the one hand, the serial, which is broadcast every other week, is difficult to follow (Ilta-Sanomat 26.2.1975). On the other, the 50-minute episodes spend too much time on to-ing and fro-ing (EteläSuomen Sanomat 1.3.1975). Hilkka Vuori (Democratic League of Finland), who was a member of the Finnish Broadcasting Company program council at the time of the Peyton Place debate, wishes that television had never 'discovered' the serial film idea. At the same time Vuori would have preferred that the serial Oi kallis kaupunki had been constructed upon with a limited number of episodes a clear and fixed plan (Kansan Uutiset 4.3.1975).

Critics accuse television of flirting with the masses, and even its psychological realism was now being more clearly challenged than before. For example Eeva-Liisa Väänänen considers how "the idiot" represented by the protagonist can in fact develop into an aware and independent citizen:

\footnotetext{
It just happens that the whole premise is very artificial although I guess it could happen that even a man with such a very good background can think. We have seen the episodes where the ground is prepared for the character and background of Aatos Eerola's (Kim Floor). We have even gone through his women, and received from Raija Koivula (Liisa Paatso) a glimpse of his obviously mandatory sex life (...). It is actually rather a pity that the series so obviously flirts with the masses and simplifies things. It scares me to think how, within this framework, we will soon be delivered political horse-trading and "losing touch with healthy thinking" when, until now, we have made do with Peyton Place like melodrama. (Liitto 5.4.1975.)
}

Affairs with women have brought an emotional dimension into the serial which was exceptional at that time in series describing politics. The serial is seen as describing a certain type of a person, an ordinary person, who has become dedicated to politics (Savon Sanomat 23.3.1975). However, some 
critique pays attention to the realistic depiction of contemporary drama, the contemplative style, the treatment of real and impressive problems, and the fairness in the portrayal of municipal politics:

\begin{abstract}
Jorma Savikko seems to denude all political parties of their masks of complacency and piety. The declarations announced and the songs sung in the heat of council elections are high-flown, but they do not keep what they promise. Particularly in the fourth episode, I thought I discerned a note of general anti-political and anti-politician attitude. I hope this note was temporary because all-over negative attitudes can hardly be used to heighten the social awareness and knowledge of the television viewing audience. (Helsingin Sanomat 27.3.1975.)
\end{abstract}

Oi kallis kaupunki did not attempt a very profound revelation. But maybe, because of this, its degree of generalization is higher. Similar observations can be made in the municipal politics of all smaller cities. The educational task was more important than the critical. Oi kallis kaupunki portrayed the making of politics as interpersonal action carried out by people which, in principle, is no dirtier than any other work but in which there is a yawning abyss between idealism and realizable practice. (Etelä-Suomen Sanomat 7.6.1975.)

However, vacillation, which is typical of municipal politics, should not be reflected as such in the development of a story line, which, when used as criticism, refers to generic realism which expects that the genre handles reality in a particular way. Aimo Siltari writes: "Savikko knows what he is doing, but such a crawling way of developing the plot blunts the edge and makes TV evenings tedious. Besides, as the episodic serial continues, there are some obvious plunges into pretentiousness." (Savon Sanomat 10.4.1975.)

For his part, Jukka Kajava is irritated by the fragmentarization typical of continual serials. The drama reminds him of Coronation Street in which there are a lot of people and a lot of detail: "The scenes are extremely short and continuity debatable with the narration jumping from one scene to the next" (Helsingin Sanomat 8.5.1975). Finally he accuses the script, the casting and direction, "which is satisfied with only elementary acting pursuits", for the failure of an inspiring program idea: "And this is how we end up with a domestic Peyton Place whose characters pose in pretty interiors, eternalized by the controlled use of the camera. (Juhani
Heikkonen's camerawork is, by the way, the best working component of Oi Kallis kaupunki)" (Helsingin Sanomat 5.6.1975.)

Unlike Pääluottamusmies, which dealt with trade union politics, the serial provokes increased criticism from the left. The treatment of political parties and working class families "with all its fairness" does not convince all reviewers in left-wing newspapers. Reviews of Oi kallis kaupunki, published especially in the newspapers of the minority branch of the Finnish People's Democratic League and the so-called Finnish Communist Party are clearly different from others. Hilkka Vuori, who is a columnist in Kansan Uutiset thinks that the serial is burdened with "gross prejudice of working class families" (Kansan Uutiset 4.3.1975).

The columnist in Hämeen Yhteistyö accuses the serial of "social democratic propaganda" which in his opinion undermines the credibility of the characters and plot. He thinks the workers seem very stupid and the communists are depicted as suppressors of leftist co-operation. The writer, L. Varras also finds it funny that "the film" talks about leftist co-operation although it contains, in his opinion, "the strongest anticommunist propaganda in many years, notwithstanding perhaps the election campaign of the Metalworkers' Union". The writer's open Taistoist ${ }^{8}$ sympathies become evident when he says:
When two sinister looking men huddle together in the corner of the meeting room you can be sure that they are Taistoists plotting away all dreams of leftist co-operation; in the next scene they are bound to vote against the common endeavor." (Hämeen Yhteistyö 15.7.1976.) ${ }^{9}$

The depiction of reality is thus accused of political favoritism especially in the mid-1970s. It is interesting that the same serial can evoke comparisons with both American television melodrama and social democratic propaganda. The narration of serial drama was temporarily moved to the domain of so called official politics (political parties, the trade union movement and the parliament). Although Rintamäkeläiset also portrays political figures and their seemingly inevitable stereotyping, the events still take place in the domain of homes and the semi-public (restaurants, schools). Narratively, things change when the camera is focused on the clubs, chambers and secret negotiations of politics. Parliamentarianism shows its darker side in fiction. However, in an estimation of realism, Oi kallis kaupunki arouses mainly positive judgments in its attempt to portray things in all their viciousness. 


\section{Flexibility of Convention}

After the medium-length situation comedies of the early 1980 s there began to be a demand for long serials towards the end of the 1980s. The production culture in TV 2 also started to change in connection with the establishment in 1987 of the Drama Group that is affiliated with entertainment programs. This boom coincided with Metsolat, which was paid for by extra funding, and Kohtaamiset ja erot, which was shot in rapid succession in Parkkuu.

Despite, and because of, various production problems, Kohtaamiset ja erot was an attractive serial idea to its makers and it was worked upon for longer than usual. A realism of its own kind was sought in the production of this serial by getting to know the locations, and by investing especially in the costumes. The press release compares the serial with its literary role models, Aapeli, Maiju Lassila and Maria Jotuni in the following way: "The setting - an insular village which gets a healthy draft of fresh air - is one of the most popular in literature, and in a similar vein, central have been the settings of the "wild goose chase", "wasted work", "who teaches whom?" and "somewhere over the rainbow" kind. Flap door Kärttämä in Karelia represents the present-day edge of Europe, with all due respect to individuals and their backgrounds." (TV 2 1994)

Kohtaamiset ja erot is loosely based on Sirkka Laine's (1989) collection of short stories by the same name. In the serial the village is centered on the local bar that is at the same time the grocery store, the bookie's office, the post office and the service station for problems of the heart (see Savon Sanomat 21.9.1994). The people of Kärttämä village have been portrayed in all their strangeness, with their ragtag notions and ideas. The language overflows with brogue and mysterious things even happen in the serial. However, according to Veijo Hietala, as a depiction of the countryside, the serial does not represent a similar "purity and innocence, time before the fall" as in Metsolat (Turun Sanomat 22.11.1995). It looks as if Hietala would like to say that one should not make a comedy of country people, that they should not be too typified. The criticism resembles a demand to describe reality while bearing in mind certain ethical principles.

The narration, which is rich with symbolism, does not in the first episode appeal to Leena Mäenpää:

The first episode goes a fair way before the first word is uttered. Places are filmed - for example, the felt boot factory. At the same time a melancholy tune is being played. A red cottage, the grocery store, and a view of the rapids: they are apparently central places in the serial. The wild boar is also an important character. Maybe it even has symbolic value. A man and a woman drive in a car. One looks at the other, then the other looks back and green fields surround them. Nondescript movie language. (Etelä-Suomen Sanomat 21.9.1994.)

The critiques written of the serial are, maybe because of the advance publicity, mainly anticipatory and positive. References especially made to the American 1990s series Northern Exposure (CBS) are noteworthy in the critique, which is mainly focused on the first episode in my sample. The author Sirkka Laine says in the channel press release that the genre is somewhere between melodrama and comedy: "I think that my sense of drama is a mixture of human nature at its most naked, passionate emotions and close family ties and quarrels on which humor descends." (TV 2 1994) Both the time and the physical environment, "the borderland" were essential elements in the serial according to its author. In the end it gave her a mental picture of timelessness, of the borderline between the old and the new, and of a mixing of cultures.

In the criticism, the serial is compared with Metsolat but the reviewers are quick to point out that "It is more fairytale-like, with more humor and even tragedy. It is not pure everyday realism. A dog may get wings, a dressmaker's dummy can come alive, and people sometimes behave totally contrary to expectations." (Kansan Uutiset 21.9.1994) The reviewers note the geography of the serial and the meaning of locality: Kärttämä village is situated between North and South Karelia. One reviewer sees a hint of "the mystical grace of Finnish folk tales and lots of quiet humor hidden beneath the melancholy exterior" and praises the serial because it is "extremely carefully and imaginatively staged (Mari Skogberg)", and that "Ilkka Järvinen's camerawork brings nature so close that you can almost smell the wind, redolent with thousands of scents" (Ilta-Sanomat 21.9.1994) Jukka Kajava first shuns the mixture of styles but then says that he has become used to it:

You can be sure that Kohtaamiset ja erot is different. It may look a little bit like any old serial with its strange characters but it is not that, it has its own unique style, which is a combination of a number of styles. However, sometimes you 
feel like saying: not like this, my good people, no - so extremely different and of various kinds, all dumped into the same package. After having seen two episodes I have to admit that my eye and my mind have become used to its kaleidoscope because there truly are human beings inside all the characters. (Helsingin Sanomat 21.9.1994.)

In the end he calls it an ambitious "folktale" which has been edited to be too fragmentary and which has become a "freak show" of too many different kinds of acting styles. He ends by noting rather bleakly: "The makers have watched too many episodes of Northern Exposure without understanding anything of its charm." (Helsingin Sanomat 22.10.1994.)

Jorma Heinonen, who wrote a number of critiques, sees the serial as "meandering between comedy and tragedy". According to him the drama's carrying force has been humaneness, a combination of different attitudes towards life, Finnishness, tension and "draftiness". To Heinonen, Kohtaamiset ja erot is "soulfulness and intensity activated by contradictions" which he seldom remembers having seen in television (Keskisuomalainen 21.9.1994). $\mathrm{He}$ is not disappointed as the serial goes on:
Even if the serial written by Sirkka Laine and directed by Kristiina Repo seemed to be too much for some people at the beginning - "a strange business" I have heard some people say - the whole thing has been kept well under control. And this means that everyday life has been depicted as a comedy and as a tragedy." (Keskisuomalainen 25.1.1995.)

The TV critic Aila-Liisa Laurila begins her article on the serial from Euro-Finland and goes on to discuss the themes of serial drama in more general terms. Unlike Veijo Hietala, who started with a similar kind of disposition, she is amazed by the worldview, "rural re-population", depicted in the serials including Metsolat and its contemporary, the TV 1 drama Kovaa maata (Hard Soil), which she sees as at odds with the country's new international position. Laurila is astonished by what the authors and viewers can find so attractive about men in old-fashioned trousers who walk the village road and go on and on about how nothing comes of nothing. She also wonders what the viewers can find attractive about hay barns, wooden cottages and the village grocery store, where the action takes place. Laurila writes:
There would now be a demand for a domestic TV serial that lives in the same world as the majority of the population. It could have as its starting point everyday life in the countryside, not just idleness or a misty dream, and life in the city, not only as bankruptcy money, and human relationships. (Aamulehti 3.12.1994.)

The writer thinks that neither the portrayal of the countryside nor city life mirrored in the serials is realistic. This portrayal does not fit into her view of how Euro-Finland should be portrayed, and she goes on to say ironically: "Finland is such a Paradise that it is really a pity that we must become members of the EU, even if it doesn't mean any significant change to the pace of life" (Aamulehti 3.12.1994). In her critique, Laurila seems not to appreciate the mythical Finnishness of the serial.

The critique written of Kohtaamiset ja erot largely conforms to the spirit of the press release. Special attention is paid to the tragi-comical point of view and expression in the serial. Moreover, Finnish television morale has been seen as demanding everyday realism from fictional serials where life is shown as every bit as hard as it is in 'reality' (for example Alasuutari 1991, 57). In this sense, Kohtaamiset ja erot does not seem to have disappointed the critics. The serial is seen to be "good-natured", although with its human relationships angle it resembles American soap operas (Savon Sanomat 21.9.1994).

\section{Reality Rhetoric in Author-Oriented Criticism}

There is no doubt that television criticism has participated in the production of the different articulations of Finnish realism, and in connection with them, the convention of social realism. Selective as it is, the convention has maintained its strength and with some exceptions, such as Kiurunkulma, which resembles journalistic drama, seems to have strengthened it. The authors of dramas are also associated with 'Finnish realism' as special witnesses and prophets, even in the television critique published in the 1990s. When it is understood in this way, the emphasis on the author resembles the idea that the reality is reflected in the writing, directing and finally, in the filming of the text of television drama. According to this extreme view, the author has not only been the source and creator of the text but also has been a special 'witness'. 
In the light of the press releases and the interviews I have conducted separately, the makers of dramas themselves emphasize the author-oriented viewpoint. The same goes for television criticism. According to the criticism, the 'witness' of Finnish culture does not necessarily have to speak Finnish as his mother tongue or even have to have been born in Finland. According to the critique, it is exactly being this cultural outsider, as in the case of, for example, Neil Hardwick and Carl Mesterton, that makes the writer so skilled at being an expert at Finnishness and its mythical aspects. This view that stresses the intention of a single author becomes clear in the critique written of Tankki täyteen and Metsolat. The female authors of the fantasy world used in Kohtaamiset ja erot, and especially its writer Sirkka Laine, are praised for the depiction of the imaginary, dreamlike mysticism of nature. At the same time, the reviews repeat on the meta-level the division between culture/nature on the one hand and masculine/feminine on the other.

On the basis of the analysis it is most interesting that sometimes a single reviewer does not only write about the drama itself but about 'the reality', which he assumes the series or serial is depicting. One can talk about reality by referring to life in the countryside, its people, manners etc., but the talk may also refer to assumed cultural pictures. Both have been typical of Finnish television critique ever since the 1960s. This 'reality rhetoric' begins somewhere in the reviewer's preconceived ideas of how s/he sees the world outside the drama, its human relationships, the things that are central both culturally and socially, and the particularly Finnish mindscape. 'Reality discourse' is strengthened by the reviewer's view of how events, people and things are customarily dealt with in earlier pictures, and especially within the particular genre. From this point of view the reviewer finally ends up constructing the world portrayed in the television series and serial.

All ways television critics write are in their essence familiar from academic television critique in which talk about the television fiction can always be attached to a certain meta-discourse (Morris $1990,22)$ and a certain anatomy of interpretation of that discourse. The meta-discourse can be sought, as in the cases I have analyzed, in a certain conception of reality, such as the empirical, the didactical, the generic, the psychological or the ethical. From the point of view of the article at hand, the particular 'reality rhetoric' is also such a meta-discourse. It has its own anatomy in those conceptual starting points with which the critic signifies 'reality' in general, and its portrayal in the television program. What is noteworthy is its transparency; in it, the critic is either completely or partially separate from the object $\mathrm{s} / \mathrm{he}$ interprets and from the task of evaluating the serial drama and writing another, parallel story.

\section{Notes}

1. Mediavirtuoosi was published during 1994-2000.

2. Two important family dramas are missing from the data. The noteworthy Kotirappu (Home Staircase) and Päin perhettä (Against the Family) remain outside the investigation because there is not enough minimum 5 reviews - archival material on them to be used as basis for analysis. When all long and mediumlength drama serials are taken into account, TV2 has in total participated in the production of 25 family dramas or other medium-length drama serials that fulfil the criteria I am using. The majority of the serials are family dramas. They portray families or their points of view and assume families or, in a wider sense, 'family interest' as their audience. In addition, a tacit agreement between the producers, critics and the audience has been reached that they are all dealing with a family drama (see in more detail Ruoho 1996).

3. According to the data, a lot of the reviews written about the TV2 long and medium-length drama series

and serials can be found in the following papers: Helsingin Sanomat, Keskisuomalainen, Aamulehti, Kansan Uutiset, Savon Sanomat, Ilta-Sanomat, Turun Sanomat and Etelä-Suomen Sanomat. In addition to Jorma Heinonen and Jukka Kajava, most of the reviews (more than 10 reviews in the data) have been written by two journalists, Marja Sjöberg (Aamulehti), Tapani Uusiniitty (Aamulehti, Etelä-Saimaa, Ilkka, Itä-Savo, Lalli, Kainuun Sanomat, Karjalan maa and Pohjolan Sanomat), A-A Tuominen (Kansan Uutiset), under the pseudonym 'Troika' (Kansan Uutiset), Aimo Siltari (Savon Sanomat), Kari Jalonen (Turun Sanomat), Leena Mäenpää (Savon Sanomat, EteläSuomen Sanomat) and Hilkka Vuori (Kansan Uutiset).

4. For example, director Jarmo Nieminen used outside broadcasting technology when he filmed the serial drama Hilma (1967-1968).

5. The group of program inspectors which was established at the time of the so called Reporadio found the time to publish one report for public discussion which 
dealt with the serial drama programs of the Broadcasting Company and Commercial TV in the early part of 1969.

6. The serial was re-run quickly in 1971-1972 and it is because of this that the reviews published at the time of the re-run are also part of the data.

7. See for example the handout "Information Warfare in Finland 1970-1971" - a collection of newspaper articles dealing with mass media policy. University of Tampere, Department of Journalism and Mass Media. Handouts 5/71.

8. The minority movement within The Finnish Communist Party was called "Taistoist" after its leader, Taisto Sinisalo. The movement was relatively powerful among university and college students at the beginning of the 1970s.

9. The serial was re-run in summer 1976.

\section{Bibliography}

Alasuutari, Pertti (1991) The Value Hierarchy of TV Programs. An Analysis of Discourses on Viewing Habits. Teoksessa Alasuutari, Pertti, Armstrong, Karen \& Kytömäki, Juha (eds.) Reality on Fiction in Finnish TV Viewing. Research Report 3/1991. Helsinki: Yleisradio, 35-62.

Ang, Ien (1985) Watching Dallas. Soap Opera and the Melodramatic Imagination. London: Methuen.

Bordwell, David (1989) Making Meaning: Inference and Rhetoric in the Interpretation of Cinema. Cambridge: Harvard University Press.

Bourdieu, Pierre (1984) Distinction. A Social Critique of the Judgement of Taste. London: Routledge \& Kegan Paul.

Bourdieu, Pierre (1998) Järjen käytännöllisyys. Toiminnan teorian lähtökohtia. [Raison pratiques. Sur la théorie de láction, 1994]. Suom. Mika Siimes. Tampere: Vastapaino.

Brunsdon, Charlotte (1989) "Text and audience". Teoksessa Ellen Seiter et al. (eds.) Remote Control. London: Routledge, 116-129

Deming, Caren (1988) "For Television-Centered Television Criticism: Lessons from Feminism". Teoksessa Anderson, James (ed.) Communication Yearbook II. London: Sage, 148-176.

Harms, Joan, Rand, Max \& Savolainen, Keijo (1979) Yleisradion ja Mainos-Television sarjafilmiohjelmisto 2.2.1969-17.5.1969.

Hartley, John (1996) Popular Reality. Journalism, Modernity, Popular Culture. London: Arnold.

Hurri, Merja (1994) "Kulttuuriosasto taistelukenttänä. Esteettinen, journalistinen ja popularisoiva kritiikki Pierre Bourdieun ja Hugh O'Duncanin näkemysten valossa". Tiedotustutkimus 17: 1, 4-13.

Jordan, Marion (1981) "Realism and Convention". Teoksessa Dyer, Richard, Geraghty, Christine, Jordan, Marion, Lovell, Terry, Paterson, Richard, and Stewart,
John (eds.) Coronation Street. London: British Film Institute, 27-39.

Kivimäki, Ari (1998) Intohimojen karuselli. Elokuvajournalismin julkisuuspelit Suomessa 1950-1962. Lisensiaatintutkimus. Turun yliopisto, kulttuurihistoria. Julkaisematon käsikirjoitus.

Moi, Toril (1990) Sukupuoli, teksti ja valta. [Sexual, textual politics]. Suom. Raija Koli. Jyväskylä: Gummerus.

Morris, Meaghan (1990) Banality in Cultural Studies. Teoksessa Mellencamp, Patricia (toim.) Logics of Television . Essays in Cultural Criticism. London: British Film Institute, 14-43.

Nelson, Robin (1997) TV Drama in Transition. Forms, Values and Cultural Change. London: Macmillan Press.

Nordenstreng, Kaarle \& Varis, Tapio (1971 (toim.) Informaatiosota Suomessa 1970-71 - kokoelma joukkotiedotuspolitiikka käsitteleviä lehtikirjoituksia. Monistesarja 5/71. Tampereen yliopisto: Tiedotusopin laitos.

O’Donnell, Hugh (2000) Good Times, Bad Times. Soap Opera and Society in Western Culture. London: Leicester University Press.

Poole, Mike (1984) "The Cult of Generalist: British Television Criticism 1936-83. Screen 25: 2, 41-61.

Ruoho, Iiris (1996) "Miehiä hermoromahduksen partaalla". Teoksessa Nikunen, Kaarina, Ruoho, Iiris ja Valaskivi, Katja (toim.) Nainen viihteenä, Mies viihdyttäjänä - viihtyykö Katsoja? Yleisradion tasaarvotoimikunnan julkaisuja. Sarja A: 1/1996. Helsinki: Yleisradio, 59-67.

Ruoho, Iiris (2000) "Double Standards in Evaluating Television. Peyton Place and Dallas in the Finnish Television Culture". Teoksessa Leppänen, Sirpa ja Kuortti, Joel (toim.) Inescapable Horizon. Culture and Context. Nykykulttuuriin tutkimusyksikön julkaisuja 64 Jyväskylän yliopisto, 229-252.

Rönty, Markku (2000) Talonpojan tappolinjalla. Televisiosarja Rintamäkeläiset 1970-luvun maaseudun ja pienviljelijöiden elämänpiirin kuvaajana sekä aikansa poliittisen ilmaston heijastajana. Tutkimuksia 1/2000. Helsinki: Yleisradio Oy

Salokangas, Raimo (1996) Aikansa oloinen: Yleisradion historia, 2 osa, 1949-1996. Helsinki: Yleisradio Oy.

Steinbock, Dan (1985) Taideteos ja taidekasvatus. Niskasen, Mollbergin, Salaman ja Turkan töitä yhteiskunnallisesta ja strukturalistisesta näkökulmasta. Jyväskylä.

Tarkka, Jukka (1979) Sodan ja rauhan miehet lehdistössä. Yleisradion vuosikirja 1978-1979. Helsinki: Yleisradio, 9-10.

Williams, Raymond (1976) Keywords. A Vocabulary of Culture and Society. London: Croom Helm.

Williams, Raymond (1977) Marxism and Literature. London: Oxford University Press.

Williams, Raymond (1989) "A Defence of Realism". Teoksessa Williams, Raymond: What I Came to Say. London: Hutchinson Radius, 226-239. 
Yleisradion ohjelmatoiminnan säännöstö 1972. Helsinki Yleisradio Oy.

Zilliacus, Ville ja Storbom N-B. (1968) "Ohjelmatoiminnan tavoitteet”. Teoksessa Stewen, Kaarle (toim.) Tämä on televisio. Opas suomalaisen tv:n maailmaan. Helsinki: Weilin+Göös, 80-87.

\section{Newspaper articles}

Aamulehti 5.10.1972: Tapani Uusiniitty, Rintamäkeä ja sen väkeä.

Aamulehti 1.12.1972: Tapani Uusiniitty, Joutava juhlahetki.

Aamulehti 29.12.1972: Tapani Uusiniitty, TV2:n syysnäytelmät.

Aamulehti/Allakka 3.12.1994: Aila-Liisa Laurila, Pussihousuissa Eurooppaan.

Etelä-Saimaa 20.2.1975: Tapani Uusiniitty, Sarjamylly pyörii.

Etelä-Suomen Sanomat 1.3.1975: Irmeli Paavola, Kaupunki kulisseissa.

Etelä-Suomen Sanomat 7.6.1975: Mika Suvioja, Parasta kotoista.

Etelä-Suomen Sanomat 21.9.1994: Leena Mäenpää, Hataraa harhailua rajan pinnassa.

Helsingin Sanomat 30.1.1973: Jukka Kajava, Missä aita on matalin.

Helsingin Sanomat 27.3.1975 Jukka Kajava, Mehuttomasti Lassilaa.

Helsingin Sanomat 8.5.1975: Jukka Kajava, Kallista, huonoa oppia ulkomailta.

Helsingin Sanomat 5.6.1975: Jukka Kajava, Päätön loppu kuin iltasadussa.

Helsingin Sanomat 21.9.1994: Jukka Kajava, Kohtaamiset ja erot -sarja on monenkirjava kyläkertomus.

Helsingin Sanomat 22.10.1994: Jukka Kajava, Menköön identiteetti.

Hämeen Yhteistyö 27.10.1970: Ahti Sala, Lupaava alku "pääluottamusmiehellä".

Hämeen Yhteistyö 15.7.1976: L. Varras, Kallis on kaupunki - ja kansa maksaa.

Hämeen Yhteistyö: 7.10. 1972: Raija Laroma, Pienviljelijän elämänmuoto.

Iisalmen Sanomat 9.7.1968: Elsa Bohm, Ykköskanavan kesävieraat.

Ilkka 27.19.1974, Tv-teatteria: Syksyn suomalainen maaseutu.

Ilta-Sanomat 26.2.1975: Ullamaija Kivikuru, Oi, kallis juonimylly.

Ilta-Sanomat 21.9.1994: Satu-Maria Niikko, Tosi ja taru kohtaavat Kärttämässä.

Itä Savo 1.3.1975: Tapani Uusiniitty, Sarjamylly pyörii.

Kainuun Sanomat 20.2.1975: Tapan Uusiniitty, Sarjamylly pyörii.

Kansan Tahto 14.8.1971: Seppo Hursti, Ristivetoa.

Kansan Uutiset 28.10.1970: Hilkka Saarikoski, Ajankohtaista ja myöhäsyntyistä kuvaruudussa.
Kansan Uutiset 2.11.1971: Hilkka Vuori, Myöhäisillan teatteria televisioruudussa.

Kansan Uutiset 4.3.1975: Hilkka Vuori, Tv-sarja - kahle kuvaruudun molemmin puolin.

Kansan Uutiset 21.9.1994: A-A. Tuominen, Ihmissuhteita Kärttämän tyyliin.

Keskisuomalainen 21.9.1994: Jorma Heinonen, Sirkka Laineen novellien pohjalta tehty sarja Kohtaamiset ja erot. Pienen kärttämän kylän ihmisten aitoa eloisuutta.

Keskisuomalainen 25.1.1995: Jorma Heinonen, Kauniit kiitokset TV2:n sarjasta.

Karjalan maa 27.10.1974: Tapani Uusiniitty, Tv-teatteria: Syksyn suomalainen maaseutu.

Lalli 27.10.1997: Tapani Uusiniitty, Tv-teatteria: Syksyn suomalainen maaseutu.

Liitto 5.4.1975: Eeva-Liisa Väänänen, “Oi kallis kaupunki” ei täyttänyt odotuksia.

Päivän Sanomat, 4.9.1967: Nimimerkki Tee Ärrä, Kiurukulma.

Savon Sanomat 23.9.1968: Jarkko Rosenlund, Peräkyläshow.

Savon Sanomat, 10.1.1969: Seppo Vallgren, Kiurunkulma on.

Savon Sanomat 30.7.1972: T-B Orsmaa, Pääluottamusmies - kohti asiaviihdettä.

Savon Sanomat 6.10.1974: Aimo Siltari, Rintamäkeläiset.

Savon Sanomat 23.3.1975: Aimo Siltari, Apinat ja ihmiset.

Savon Sanomat 10.4.1975: Aimo Siltari, Savikon tapaan.

Savon Sanomat 21.9.1994: Pauliina Pulkkinen, Salaiset suhteet Kärttämän arkipäivää.

Suomenmaa 29.10.1968: I.O, Apua Kiurunkulmalle.

Turun Päivälehti 14.6.1975: Markku Rintanen, Romanttista kuvitusta.

Turun Sanomat 2.6.1968; Kari Jalonen, Suomalainen sarjanäytelmä II.

Turun Sanomat 26.10.1970: Kari Jalonen, Pääluottamusmiehen kokokuvaa.

Turun Sanomat 22.11.1995: Veijo Hietala, Metsolat jälleen ruudussa. Kansa palaa juurilleen .... Haastajista ei ollut ohittajiksi.

Uusi Suomi 7.6.1975: Pentti Pirhonen, Ei kallis kaupunki ansioton ollut.

Vaasa 4.5.1969: Nimimerkki Puntari, Tv-tuumat.

\section{Interviews}

Nättilä, Pertti 22.5.1996

Niilekselä, Jussi 28.10.1996.

Laine, Sirkka 22.10.1996

Savikko, Jorma, 10.9.1996.

Silvasti, Eero 16.9.1996.

\section{Other sources}

TV2 1971, press release 9.8.1971. TV2 1975, press release 11.2.1975. TV2 1994, press release 21.9.1994. 